\title{
Going Concern of Sambu Barumbun Metaphor in Mamasa Culture, West Sulawesi Indonesia
}

\author{
Natalia Paranoan ${ }^{1}$, Julianty ${ }^{2}$, Afian Dezi Sanda Sipi ${ }^{3}$, Anthon Paranoan ${ }^{4}$, Nur Eny ${ }^{5}$ \\ Department of Accounting, Faculty of Economics and Business, Universitas Kristen Indonesia \\ Paulus 1,2,3, Department of IT, Faculty of Information Technology and Computer, Universitas \\ Kristen Indonesia Paulus ${ }^{4}$, Department of Accounting, Faculty of Economics and Business, \\ Makassar State University ${ }^{5}$ \\ \{nurenylolo@gmail.com ${ }^{1}$ \}
}

\begin{abstract}
This study reveals a going concern with cultural metaphors. This study aims to reveal the concept of sustainability (going concern) in the metaphor of the cultural products of Sambu 'Barumbun in Mamasa Regency, West Sulawesi, Indonesia, which still exists today. The research method in this study is a qualitative method through observation, interviews and documentation. Data obtained by interviewing four informants who know clearly the object under study. The data were analyzed using semiotic analysis, namely the study of signs, in which the meaning of each person will be different according to culture, ideology, and experience. The results of this study indicate that Sambu 'Barumbun has a going concern concept which is used when customary activities are also used as a source of income for the Mamasa community.
\end{abstract}

Keywords: Going Concern; Sambu' Barumbun

\section{Introduction}

The success of a company can be seen from the ability to maintain the viability of its business for a long time and be able to face various situations. The company's goal is to maximize profit (profit): [1]. To continue to make profits, the company must be able to maintain its business continuity. A company can be called a going concern if it has been operating for a long time and has no limits, meaning that the sustainability of a business is not limited to how long it will operate, and its condition can survive and even continue to develop both financially and non-financially. Going concern is a basic assumption in the preparation of financial statements, a company is assumed to have no intention or desire to liquidate or even materially reduce its business scale: [2]. Going concern is an assumption that assumes that an entity will be able to operate in the long term.

In order for the company to survive it must have good management. Business continuity is always associated with a management's ability to run a company in order to survive [3]. Financial reports provided by management are a form of accountability to the public, especially shareholders. The financial statements contain information so that shareholders can make decisions for the next continuity of the company. 
Not only in the company, culture also applies the concept of going concern, one of which is Sambu 'Barumbun. Sambu 'Barumbun is a typical Mamasa woven cloth which is a cultural heritage and is one of the characteristics of the Mamasa area. Sambu 'Barumbun can be related to the concept of going concern because Sambu' Barumbun also has a concept of sustainability, where Sambu 'Barumbun has existed since ancient times and was used by the community at that time when conducting traditional events, be it weddings, thanksgiving or grief events. Until now, Sambu 'Barumbun still exists and even continues to grow, not only used during traditional events but the Mamasa community maintains the preservation of Sambu' Barumbun by making this Sambu 'Barumbun a work of art and making it a source of income.

Various studies discuss going concern, including research by [4]; [5]; [6]; [7]. However, there are not many links going concern with culture. Indonesia is a country that has various cultures that can be related to accounting science so that discussion of accounting does not only concern numbers but can also be related to culture [8]; [9]. Research that reveals the concept of going concern that does not only apply to companies but also from a cultural point of view has been carried out by previous researchers including [10] who examined Going Concern in the Ondel-ondel Metaphor. The result of this research is that Ondel-ondel was originally a symbol of repelling Bala for the Betawi people, one of the ethnic groups in Indonesia, but has now evolved into "street singers". Ondel-ondel going concern by evolving from worship media to entertainment media along with the times.

Culture is a way of life for society that continues to develop and is passed on to the next generation. Likewise, the woven cloth called Sambu 'barumbun is an inheritance from our ancestors from generation to generation as a result of customs and habits as well as art that continues to develop in society. Going concern as a concept of sustainability has a principle to survive and continue to develop or continue. This principle applies naturally to all living things, namely having the desire to survive and continue life even to develop. This going concern principle must be adhered to if you want to survive or continue to exist. Sambu 'Barumbun which is still around until now although many woven fabrics have sprung up, but Sambu' Barumbun has also survived and even continues to develop in the midst of an increasingly modern era.

The purpose of this research is to reveal the concept of sustainability (going concern) Sambu 'Barumbun in Mamasa Regency, Indonesia so that it is still alive today. This research can provide the following benefits: 1) Theoretical benefits, this research is expected to provide benefits and knowledge about the concept of sustainability or going concern from Sambu 'Barumbun. 2) practical benefits; The results of this study can be a reference for local governments in terms of culture, especially Sambu 'Barumbun and can be an input to optimally support the development of existing culture in Mamasa, and can provide information for further researchers.

\section{Research Methods}

The location in this study is Orobua Village, Sesenapadang District, Mamasa Regency, West Sulawesi Province, Indonesia. This location was chosen because the village is one of the villages that has a long history of forming Sambu 'Barumbun in Mamasa Regency. Research informants are people who have information about the object of research. The information in this study is derived from direct interviews with informants who are determined using purposive sampling technique, in which informants are selected with certain considerations 
and goals, namely those who really master the object to be studied. As for those who became informants in this study were:

a. Mr Deppagoga ', 72 years old, is a traditional leader in the Mamasa area.

b. Ibu Bulawan, 67 years old, is a cultural observer in the Sesenapadang sub-district, Mamasa district.

c. Mr Alex Palullungan, 37 years old, works as a Civil Servant. He is a descendant of nobility in Sesenapadang District.

d. Ibu Tikulangi 'is 35 years old and is a craftsman of Sambu' Barumbun woven cloth.

Data collection is a step in the scientific method through logical systematic procedures and a valid data disbursement process, either obtained directly (primary) or indirectly (secondary). To obtain the necessary data and information, data and information collection is carried out. through observation, interviews, and documentation. The data analysis method used in this research is qualitative research with a semiotic approach. [11] stated that the analysis had started since formulating and explaining the problem, before going into the field, and continued until the writing of the research results. The data obtained, both primary and secondary data, were analyzed and then presented descriptively qualitatively, namely explaining, describing, and describing the problems that are closely related to this research.

In semiotic terms, the most important thing is the meaning of the sign itself. Semiotic analysis is the study of signs, where the meaning of each person varies according to culture, ideology, experience, and so on. Therefore, Sambu 'Barumbun as a product of semiotic culture can be the object of semiotic analysis when it is related to accounting. Most semiotic thinking involves a basic idea which asserts that meaning arises from the relationship between three things, namely objects (or the object), humans (interpreters), and signs [12],[13]. Thus, qualitative methods will be more appropriate to use a semiotic approach because qualitative research methods are subjective so that the research instrument is the researcher himself [14].

\section{Results and Discussions}

\subsection{The history of Sambu 'Barumbun}

Sambu'Barumbun is a typical cloth originating from the Mamasa district which is made by weaving. Initially, Sambu 'Barumbun was made of cotton which was spun manually and the colors used are still using the dyes they mix themselves. The coloring uses a type of wood or plant that is made by pounding or cooking it until it produces the desired color. "Sambu'Barumbun has four levels before becoming Sambu'Barumbun. The sarong or sambu 'which was first used by the Mamasa community at that time was called the Tannun Kano (Plain weave). This woven was plain white or without any motive. The second Sambu 'is Sambu' Bembe which has a white color and has been given a red motif on the edges. The third is the sambu 'or dodo Pa'lak, this Sambu' has a color like the red and white flag that alternates between the sambu'. The fourth is Sambu 'barumbun,"

In the past the use of Sambu 'Barumbun' during Sara 'Tuka' (wedding ceremony) using Sambu 'Barumbun Riri (yellow) and at Sara' Solo '(funeral ceremony) namely Barumbun Lotong (black), both of these things apply to society the usual. For people with a higher rank (nobility) use the red Sambu 'Barumbun at Sara' Tuka '(wedding ceremony).

\subsection{Going Concern and Sambu 'Barumbun}


Going concern is a condition in which the company has operated for a long time which is influenced by financial and non-financial conditions and will not be liquidated in the short term [15]. Going Concern is one of the requirements for a company to survive and develop. Related to culture, this Sambu 'Barumbun is also a cultural product that has survived. As stated by one of the informants, Mr. Alex Palullungan: "The cultural heritage of Sambu" Barumbun must be preserved because in addition to respecting our ancestors who have left the cultural heritage, it is also Sambu "Barumbun has become one of our characteristics as Mamasa people."

According to Ibu Tikulangi ': "Sambu" Barumbun will continue to exist as long as the culture in Mamasa still exists and in particular we as weavers, Sambu "Barumbun is one of our sources of income".

Similar to a company, Sambu 'barumbun also has a concept of sustainability. Sambu 'barumbun still exists today because apart from being used during traditional events, Sambu' barumbun is also used as a business area that benefits the craftsmen.

\subsection{The Meaning of Sambu 'Barumbun as a Cultural Symbol}

The preservation of Sambu 'Barumbun as one of the cultural symbols of Mamasa district is also a sign of a going concern in accounting. Symbols are indispensable for the benefit of deepening the values represented even though symbols are not values themselves, for example, such as religious values, social life and science. Symbols are also not only in the form of visible objects but also through speech or movement. So, symbols have an important meaning in a culture because symbols are a picture of the world, as we see it every day. Humans need symbols to know something and also symbols can be used to help solve various problems and can also provide solutions to the problems we are facing. The symbols contained in the sambu 'barumbun are icons, traditional ceremonies, motives, and colors.

First, the icon. Sambu 'barumbun as an icon symbolizes one of the cultural symbols of Mamasa district which is also known as one of Indonesian culture. The use of Sambu 'barumbun as a symbol so that its sustainability is maintained or not extinct and is not eroded by modern fabrics. Interview with Mr Deppagoga ':

"Sambu" Barumbun must be preserved, because like us as traditional leaders, if there are traditional events, Sambu "barumbun is definitely used in the event, that is what is inherited from our ancestors. So things like this we cannot get rid of, although now there are many fabrics out there but Sambu 'barumbun has become a characteristic of us as Mamasa people, becoming our icon "

Apart from being a symbol when carrying out customary activities which can only be used by certain people, it is now a source of livelihood for some of the Mamasa community. Second, the Traditional Ceremonies (traditional ceremonies). Mamasa Regency has a variety of very unique cultures, one of which is the traditional ceremony. Traditional ceremonies that are closely related to the life of the Mamasa community are the Death Ceremony and the Wedding Ceremony. Both the wedding ceremony and the funeral ceremony, this Sambu 'Barumbun is always used.

Interview with Ibu Tikulangi ': "There are two things that are most important in life, back then until now, namely Sara 'Tuka' (Wedding Ceremony) and Sara 'Solo' (Death Ceremony), Sambu 'Barumbun is used in both traditional ceremonies. Therefore, Sambu 'Barumbun will remain as long as the culture in Mamasa still exists. " 
These two things, the Death Ceremony and marriage always go hand in hand and never be separated from the life of the community, especially the Mamasa community. Based on the results of the interviews with the informants above, it can be seen that Sambu 'Barumbun will still exist if the culture in that society still exists. In accounting, it is also paired, debit and credit (Weygant, Kieso, Donald, \& Kimmel, 2012 in [10]. Every transaction in accounting greatly affects debit and credit, so that debit and credit are very important and cannot be separated from each other [16]. Pairing is a requirement in accounting so that going concern always has a balance point. Likewise with the use of Sambu 'Barumbun during traditional ceremonies that cannot be separated from community life.

Third, motive. The Sambu 'Barumbun motif is very important because it makes the appearance more attractive and varied. However, the giving of motifs to the weaving is not arbitrary, apart from the fact that the making of the motifs is quite difficult as well because there are certain motifs that cannot be inserted carelessly into the weaving and may not be used carelessly by people in ancient times. According to Ibu Bulawan: "There are three motives that should not be included in the Sambu 'barumbun', namely the Sungki motif, the banua motif and the Gayang motif. The rest of the motive is only a variation because the making of the Sambu motif "is also rather difficult".

First, Sungki 'motive. This motif may only be used by people whose ancestors or family members have died who are wrapped in cloth. If the deceased family has not used this motif, the Sambu 'barumbun which has the Sungki' motif cannot be used. Similar to the Banua motif (traditional house) and gayang motif (keris), the Banua motif can only be worn when the person already owns a traditional house or when a family member dies, a traditional House Ornament is made. The gayang motif can only be used by the rich and if a family member dies, the Gayang or Keris will be hung.

The three motifs in Sambu 'Barumbun can only be used in accordance with the regulations that were in effect at that time, namely the aristocracy or the rich in ancient times. The same is the case with financial statements which must be in accordance with established standards and not made arbitrarily without following existing standards. Financial standards that apply in accounting, namely PSAK-IFRS (Statement of Financial Accounting Standards-International Financial Report Standard, which are used by bodies that have public responsibility, such as entities that are still registered in the capital market, for example insurance companies, stateowned enterprises, banks, public companies and companies). for pension funds. SAK-ETAP (Financial Accounting Standards for Entities without Public Accounting) is used by agencies whose accountability is not relevant to the public and financial reports are presented only for external users. PSAK-Syariah is used as a guideline by sharia institutions such as sharia pawnshops, zakat, Islamic banks and others. SAP (Government Accounting Standards) is established for business entities as a regulation from the government to compile Central government financial reports and Regional government financial reports.

Fourth, color. Color also plays an important role in Sambu 'Barumbun because it can make Sambu' barumbun look more attractive. However, in ancient times there were certain colors that had a higher value than others. According to Mr Alex Palullungan: "Sambu" Barumbun has 3 colors that are higher than the other colors, namely red, yellow, and black. These three colors should not be used carelessly in ancient times, only by the nobility at that time and the lower classes should not wear them. If anyone violates it, they will be subject to customary sanctions in effect at that time. "

These three colors are the distinguishing characteristics of Sambu 'Barumbun and can only be used by people who have power, in this case the aristocracy, and are regulated in customary rules that apply even though they are not written but are still obeyed by the community. The 
color on Sambu 'Barumbun is a sign of power or a symbol of legitimacy. After becoming an icon of Mamasa Culture, Sambu 'Barumbun will continue to be a Going Concern. Accounting also has legitimacy supported by applicable regulations and laws. This legitimacy is a sign of a going concern.

However, giving patterns and colors in ancient times is different from now. The giving of motifs and colors in ancient times should not be arbitrary because there are certain colors and motifs that cannot be used by just anyone, only for the use of aristocrats and traditional leaders. But now the motifs and colors have been used by just anyone because the social status of society has changed.

Table 1. Accounting concepts and metaphors of Sambu 'Barumbun

\begin{tabular}{clc}
\hline \multicolumn{1}{c}{ ACCOUNTING } & SAMBU' BARUMBUN \\
\hline 1. & $\begin{array}{l}\text { Financial Accounting Standards (PSAK, } \\
\text { ETAP, EMKM) }\end{array}$ & $\begin{array}{c}\text { Sungki Motif', Banua Motif and } \\
\text { Gayang Motif }\end{array}$ \\
2. $\begin{array}{l}\text { Government Accounting Standards, } \\
\text { International Financial Reporting Standard } \\
\text { Shariah Accounting Standards } \\
\text { Territorial legitimacy and power }\end{array}$ & $\begin{array}{l}\text { The colors in Sambu 'Barumbun are } \\
\text { red, yellow, and black }\end{array}$ \\
\hline \multicolumn{2}{c}{ Source: Processed data }
\end{tabular}

\subsection{Sambu 'Barumbun price setting}

In general, all humans, both consciously and unconsciously, have carried out the accounting process in their daily lives, because everyone is certainly never separated from activities in the process of fulfilling their daily needs [21]. Every company or business actor will definitely make transactions in their business [17], [18]. An accounting transaction is an agreement between two parties in which one party becomes a seller of goods or services and the other party as a buyer of goods or services offered by the first party. The conditions for a transaction to occur are if the transaction carried out has a financial impact both now and in the future [19], [20]. Because it has a financial impact, the transaction must be able to express its value or size in terms of money.

In this case, transactions also occur in Sambu 'Barumbun. Sambu 'Barumbun going concern by turning it into business land or a source of livelihood for some Mamasa residents so that transactions occur, namely the sale and purchase of Sambu' Barumbun. Interview with Tikulangi 'said that: "Sambu" Barumbun is made with the basic material of yarn, the price of the yarn is around IDR 19,000/ box and it takes about eight boxes of thread to make one Sambu "Barumbun and it takes about one to two weeks."

Based on the results of the interview above, it can be seen that if making one Sambu 'Barumbun' takes approximately one week, then in a month there are two Sambu 'that can be made. In making Sambu' Barumbun', it does not require a lot of money, but it takes patience, diligence, and carefulness in order to make Sambu 'according to the wishes of the customer or customer. However, because it is a daily routine, it is not a problem for the craftsmen. Sambu 'Barumbun is sold at various prices ranging from IDR 350,000 and the most expensive is Sambu' Bembe around IDR 800,000.

Based on interviews with informants, it was stated that labor costs were not taken into account because they were considered profits. This is different from the cost of goods sold concept in general accounting concepts. 


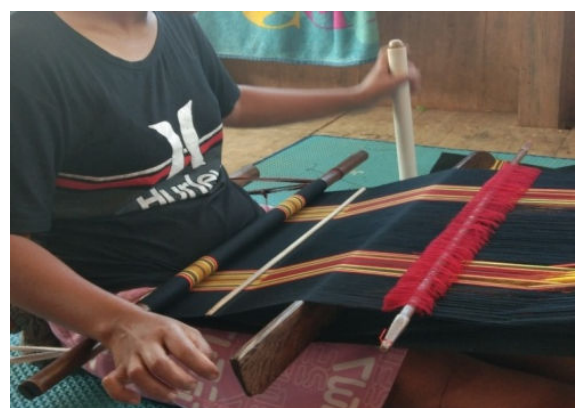

Fig. 1. The process of weaving cloth

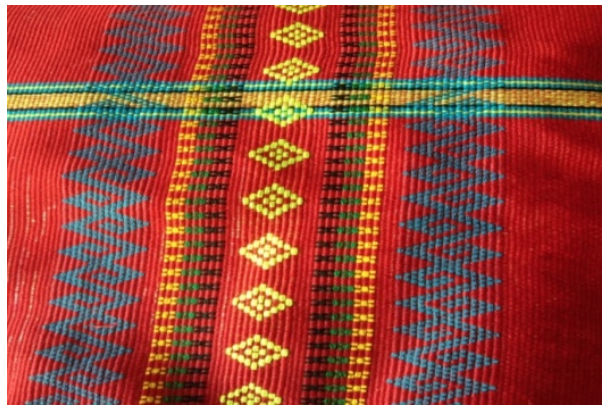

Fig. 2. Sungki' Motive

\section{Conclusion}

A company that adheres to the Going Concern principle means that the company wants to continue operating for a long time. If you want to continue operating, the company must earn a profit or profit. The same is the case with Sambu 'Barumbun who also wants to maintain himself so as not to be eroded by the increasingly modern era. Therefore, Sambu 'Barumbun Going is concerned with being a business area for some of the Mamasa community so that it can provide benefits for its users and provide benefits for the craftsmen as a source of their livelihoods and Sambu' Barumbun is also always used when there are ceremonies related with Mamasa Customs.

The principles in Going Concern show that all those who play a role in a business, organization or individual are the same as Sambu 'Barumbun as a Cultural Performer. Of course, these cultural actors must adhere to the Going Concern principle so that they can survive in this increasingly modern era. Likewise with Sambu 'Barumbun must be able to provide benefits for its users as well as provide benefits for the craftsmen as a source of their income.

\section{References} Musfiroh,
http://coreaccountingindonesia.blogspot.com/2018/08/pengertian-tujuan- 
perusahaan.html

[2] Istikharoh. (2019). Opini Audit Going Concern (Studi Empiris pada Perusahaan Pertambangan yang Terdaftar di Bursa Efek Indonesia Periode 2013-2017). http://eprints.iain-surakarta.ac.id/3621/

[3] Sandria, F. (2019). Pengaruh Financial Distress, Profitabilitas, Leverage, Dan Likuiditas Terhadap Opini Audit Going Concern (Studi Empiris Perusahaan Manufaktur Yang Terdaftar Di Bursa Efek Indonesia Periode 2010-2016). https://eprints.umk.ac.id/10698/2/Bab I.pdf

[4] Santosa S dan D. Untari. 2017. The Effect of Corporate Governance Mechanism, Company's Growth and Company Toward Going Concern Audit Opinion in NonFinancial Service Companies for the Period of 2012-2015. Journal of Applied Accounting and Finance. Vol. 1, No.2.

[5] Wulandari R \& I. Nuryana. 2018. Opinion Analysis Going Concern Through Auditor Quality and Auditor Experience. Jurnal Ilmiah Bisnis dan Ekonomi Asia. Vol. 12, No.

[6] Gunawan K.S., A. Yuesti dan P. Kepramareni. 2019. Going Concern Audit Opinion and Corporate Governance in Manufacturing Companies Listed on BEI . International Journal of Sustainability Education and Global Creative Economic (IJSEGCE). Vol. 2, No. 3.

[7] Ramadhani. F.T. dan W. Sulistyowati. 2020. Detection of Going Concern Audit Opinion based on Disclosure, Financial Condition and Opinion Shopping. Jurnal Ilmiah Akuntansi Universitas Pamulang. Vol. 8, No. 1. Ramadhani. F.T. dan W. Sulistyowati. 2020. Detection of Going Concern Audit Opinion based on Disclosure, Financial Condition and Opinion Shopping. Jurnal Ilmiah Akuntansi Universitas Pamulang. Vol. 8, No. 1.

[8] Paranoan N. dan E. Pasanda. 2017. Power Behind Price Determination in Torajanese. Journal Research of Financial and Accounting (JRFA). Vol 8(6).

[9] Paranoan N. P.P.Roreng, C..J.Tandirerung , E.S.Tandungan. 2018. Disclosing Professionalism Behavior of Internal Auditor in Preventing Fraud by Using The Local Culture Wisdom "Longko". Proceeding ICOI (International Conference of Organizational Innovation), Fukuoka University, Japan.

[10] Ttotanan, C and N. Paranoan. Setiawan, S. (2020). Pengertian Analisis Data - Tujuan, Prosedur, Jenis, Kuantitatif,Kuantitatif, Para Ahli. https://www.gurupendidikan.co.id/pengertian-analisis-data/

[11] Kriyantono. (2007). Semiotika : Simbol, Tanda, dan Konstruksi Makna. diakses pada arifbudi.lecture.ub.ac id/2014/03 semiotik-simbol-tanda-dan-konstruksi-makna.

[12] Fauziah, T. R. (2016). Representasi Sensualitas Perempuan Dalam Iklan. http://repository.upi.edu/26922/6/S_IKOM_1200147_Chapter3.pdf

[13] Creswell, 2007. Qualitatif Inquiry \& Research Design. Second Edition. Sage Publication London, New Delhi.

[14] Fairuzeff. (2012). apa yang dimaksud perusahaan going concern. https://fairuzabadizef.com/2012/12/23/apa-yang-dimaksud-perusahaan-yang-goingconcern/

[15] Maulina, R. (2019). Penggunaan Debit dan Kredit Akuntansi yang Perlu Dipahami. https://www.jurnal.id/id/blog/penggunaan-debit-dan-kredit-akuntansi-yang-perlu dipahami/

[16] Utami, N. W. (2020). Penetapan Harga, Tujuan, Metode dan Strategi. https:/www.jurnal.id/id/blog/pengertian-penetapan-harga-tujuan-metode-dan-strategi/

[17] Ridhawaty, R. (2013). Pertimbangan Auditor atas kemampuan Entitas 
mempertahankan

kelangsungan

hidupnya.

https://www.scribd.com/doc/128269441/PSA-No-30-Pertimbangan-Auditor-Atas-

Kemampuan-Entitas-SA-Seksi-341

[18] Paranoan. N. dan W. Tikupasang. 2013. Traditional Accounting Practice in Toraja South Sulawesi. E-book. Reviving The Negledted Knowledge.

[19] Team, Z. (2017). Transaksi Akuntansi, Apakah Itu? Apa Perbedaanya dengan Transaksi? https://zahiraccounting.com/id/blog/transaksi-akuntansi-apakah-itu-apaperbedaanya-dengan-transaksi/

[20] Paranoan N. \& C. Totanan. 2018. Akuntabilitas Berbasis Karma. Jurnal Akuntansi dan Bisnis. Vol.13, No.2. 